Abstracta Iranica Abstracta Iranica

Revue bibliographique pour le domaine irano-aryen

Volume 40-41 | 2019

Comptes rendus des publications de 2017-2018

\title{
Massumeh Farhad, Mary McWilliams, Simon Rettig. A Collector's Passion. Ezzat-Malek Soudavar and Persian Lacquer
}

\section{Iván Szántó}

\section{(2) OpenEdition \\ Journals}

Electronic version

URL: http://journals.openedition.org/abstractairanica/50612

DOI: 10.4000/abstractairanica.50612

ISBN: 1961-960X

ISSN: 1961-960X

Publisher:

CNRS (UMR 7528 Mondes iraniens et indiens), Éditions de l'IFRI

\section{Electronic reference}

Iván Szántó, "Massumeh Farhad, Mary McWilliams, Simon Rettig. A Collector's Passion. Ezzat-Malek Soudavar and Persian Lacquer", Abstracta Iranica [Online], Volume 40-41 | 2019, document 18, Online since 30 December 2019, connection on 21 April 2021. URL: http://journals.openedition.org/ abstractairanica/50612 ; DOI: https://doi.org/10.4000/abstractairanica.50612

This text was automatically generated on 21 April 2021.

Tous droits réservés 


\title{
Massumeh Farhad, Mary McWilliams, Simon Rettig. A Collector's Passion. Ezzat-Malek Soudavar and Persian Lacquer
}

\author{
Iván Szántó
}

\section{REFERENCES}

Massumeh Farhad, Mary McWilliams, Simon Rettig. A Collector's Passion. Ezzat-Malek Soudavar and Persian Lacquer. Washington, DC - Cambridge, MA: Freer Gallery of Art and the Arthur M. Sackler Gallery, Smithsonian Institution / Harvard Art Museums / Arthur M. Sackler Museum, 2017, p. 174, ISBN: 9780934683419

1 The catalogue contains three essays (pp.15-48) which are followed by detailed descriptions of 20 highlights (p. 49-89) and a short checklist of each of the 184 objects exhibited (p.91-160). It is dedicated to the memory of Ezzat-Malek Soudavar (1913-2014), as the exhibition itself commemorated the partial donation of her rich Qajar collection to the Harvard Art Museums in Cambridge, Massachusetts, and the Smithsonian Institution, Washington, by the deceased collector's son, Abolala Soudavar (other parts of the collection are now in Tehran - where Ezzat-Malek Soudavar lived - , Houston, New York, and Paris).

The first study offers the personal recollections of Abolala Soudavar about her mother, as well as a biographic account of Ezzat-Malek Soudavar, whose life spanned more than a century from the Qajar period to well into the 2010s and whose father, Haaj Husayn $\bar{A} q \bar{a}$ Malik, was the wealthiest merchant of late-Qajar Iran (p. 15-25). This inheritance positioned Ezzat-Malek Soudavar in the epicentre of 20th-century Iranian politics and economics, although it was not until the 1950s that she would become more interested in collecting the then rather out-of-fashion masterpieces of Qajar art. In the next essay, 
Mary McWilliams singles out the qalamdāns (pen cases) from the collection and analyses the iconography of selected examples, with particular attention to those which belong to the Isfahān circle of the artist Najaf 'Alī (p. 27-37). In the third and last study, Katherine Eremin and Claire Grech present the results of technical researches regarding the structure and material components of key items from the collection.

\section{AUTHORS}

\section{IVÁN SZÁNTÓ}

Eötvös Loránd University, Budapest 